\title{
STUDIES ON A PROTEOLYTIC ENZYME SYSTEM OF THE BLOOD. I. INHIBITION OF FIBRINOLYSIN ${ }^{1}$
}

\author{
By JESSICA H. LEWIS AND JOHN H. FERGUSON \\ WITH THE TECHNICAL ASSISTANCE OF ANN C. HOWE \\ (From the Department of Physiology, University of North Carolina, Chapel Hill)
}

(Submitted for publication September 27, 1949; accepted, December 28, 1949)

The inhibitory effect of normal serum on certain proteolytic enzymes has been recognized since the end of the century. Grob (1) has presented an excellent historical review of the subject. Serum antifibrinolysin (antiplasmin) content has been determined by a number of methods, involving measurement of the decrease in activity of a standard enzyme solution with employment of various substrates for measurement of this enzyme activity and differing also in the type of standard enzyme used. The present method has been adapted from that of Kaplan (2) and employs the rate of fibrinolysis as a measurement of proteolytic activity and, for routine use, human plasma Fraction III-3 as a standard enzyme. This method differs from that of Guest and his associates (3) only in the size and technique of clot formation and lytic endpoint and in the use of human, rather than bovine, fibrinolysin. Guest found rather marked species variations in inhibitory effects of sera on bovine fibrinolysin. We have studied the inhibitory actions of human, dog and bovine sera on fibrinolysins prepared from each of these species. Fibrinolysin may also be inhibited by certain purified trypsin inhibitors of animal and vegetable origin. We have compared the action of some of these inhibitors with that of whole human serum and of a highly purified bovine serum antifibrinolysin prepared by Loomis, Ryder and George (4). Many theories have been presented as to the nature of the antiproteolytic power of serum. Hedin (5) has suggested that this antilytic action is due to the absorption of lysin on to serum albumin. The observation that trypsin is inhibited by the products of its digestion (Bayliss [6], Northrop [7]) suggested that fibrinolysin might be inhibited in a similar fashion. We have included some data concerning these possibilities.

1 This investigation was supported (in part) by a research grant from the Division of Research Grants and Fellowships of the National Institutes of Health, U. S. Public Health Service.

\section{MATERIALS}

Borate buffer (buffer) : Each liter contained 11.25 gms. $\mathrm{H}_{3} \mathrm{BO}_{3}, 2.25$ gms. $\mathrm{NaCl}$ and 4 gms. $\mathrm{Na}_{2} \mathrm{~B}_{4} \mathrm{O}_{7} \cdot 10 \mathrm{H}_{2} \mathrm{O}$. $\mathrm{pH}=7.75$. Specific resistance $=170$ ohms $\left(21^{\circ}\right.$ C. $)$. Unless otherwise stated, this was used as a solvent and diluent throughout. Its mild bacteriostatic action was of some value in the preservation of our non-sterile protein solutions.

Fibrinogen: One per cent solution of Armour's bovine Fraction I, the dried material containing approximately 60 per cent clottable protein.

Thrombin: Upjohn's bovine thrombin, supplied through the courtesy of Dr. J. T. Correll, and prepared to contain 10 units per cc.

\section{Fibrinolysin preparations:}

1. Human: The human plasma Fraction III-3 2 (8) was dissolved in buffer to desired strength. Fresh solutions were prepared for each day's experiments and were kept in an icebath throughout the experimental period.

2. Bovine: A similar solution was prepared from Loomis' fibrinolysin (9), a fraction of bovine serum. For this and the corresponding antifibrinolysin (LA) we are indebted to Dr. Loomis and the Parke, Davis laboratories.

3. Dog: Dog serum fibrinolysin was prepared in this laboratory by the following method. The $\mathrm{pH}$ of fresh or previously frozen serum was adjusted to 5.3 by addition of 1 per cent acetic acid. After cooling to $0^{\circ} \mathrm{C}$., sufficient cold absolute ethyl alcohol was added to bring the ethanol concentration to 25 per cent. After standing one hour at $0^{\circ} \mathrm{C}$., the precipitate was collected by centrifugation and redissolved in a volume of buffer equal to half of the original serum volume. The solution was treated by shaking, at intervals, for one hour at room temperature, with $1 / 2$ volume of chloroform. Excess chloroform and denatured protein material were removed by centrifugation and the solution, still saturated with chloroform, allowed to stand at $0^{\circ} \mathrm{C}$. for from two to six weeks. During this time marked proteolytic activity appeared and the point of complete activation was taken as that time

2 The product of plasma fractionation employed in this work was obtained through the courtesy of Dr. J. T. Edsall. It was developed from blood, collected by the American Red Cross, by the Department of Physical Chemistry, Harvard Medical School, Boston, under a contract, recommended by the Committee on Medical Research, between the Office of Scientific Research and Development and Harvard University. 
at which staphylokinase treatment no longer produced additional activity. Remaining traces of chloroform were then removed by passing a current of air through the solution and it was either used directly by diluting to desired strength with buffer or was reprecipitated at 25 per cent alcoholic concentration $\left(0^{\circ}\right.$ C. $)$ and dried by alternate washings with cold absolute alcohol and cold absolute ether.

Antifibrinolysin (antilysin) preparations:

1. Soybean inhibitor (SBI): A crystalline trypsininhibitor prepared and supplied through the courtesy of Dr. M. Kunitz (10).

2. Navy bean inhibitor (NBI): Another crystallized trypsin-inhibitor prepared and supplied through the courtesy of Dr. D. E. Bowman (11).

3. Pancreatic inhibitor (Pan I): A highly purified trypsin-inhibitor. Lot No. PA-9T-1, from bovine pancreas, kindly supplied by Dr. L. A. Kazal (Sharp and Dohme Laboratory).

4. Human serum antilysin (HS) : Fresh or frozen human serum, used in dilutions stated.

5. Dog serum antilysin (DS): Fresh or frozen dog serum or dilution.

6. Bovine serum antilysins (BS) : Fresh or frozen bovine serum or dilution.

fibrinolysin (4).

(LA) : Loomis' bovine anti-

\section{METHODS}

Assay of fibrinolysin (lysin) : Fibrinolytic activity was assayed by the rate of lysis of a standard fibrin clot, adapted from that used by Kaplan (2). This standard clot contained a total volume of $2.2 \mathrm{cc}$., of which $0.2 \mathrm{cc}$. was 10 units per cc. thrombin, $0.5 \mathrm{cc}$. was fibrinogen ( 1 per cent bovine Fraction I) and $1.5 \mathrm{cc}$. were buffer or test materials. Lysis time was measured at $37^{\circ} \mathrm{C}$. with a stopwatch from the time of mixing to the time of complete dissolution of the gelatinous fibrin clot. Time of mixing, rather than time of clotting, was chosen as the starting point, since fibrinogenolysis proceeds at a rate similar to fibrinolysis. ${ }^{3}$

Lysis time was found to be directly proportional to fibrinogen concentration between 0.03 and 0.27 per cent fibrinogen (clottable protein), confirming the observations of Guest, Ware and Seegers (12). In our standard fibrin clot the final concentration of fibrin was 0.136 per cent.

3 This was shown by preparing simultaneously a series of similar lysis (fibrinolysin and fibrinogen) tubes, to the first of which thrombin was added immediately and fibrinolysis time recorded, while to the remaining tubes thrombin was added at progressive intervals until no clot was observed. The period of fibrinolysin-fibrinogen interaction, following which no clot was formed after addition of strong thrombin, was taken as the fibrinogenolysis time. Three such determinations, employing the same fibrinolysin, gave both fibrinolysis times and fibrinogenolysis times of six minutes \pm 15 seconds.
The concentration of added thrombin could be varied from 1 to 50 units without affecting lysis time. The optimum $\mathrm{pH}$ for clot lysis was found to be between 7.75 and 8.25.

Precise dilutions of human, dog, and bovine fibrinolysins were prepared and curves relating lysis times of the standard fibrin clot to the concentrations of fibrinolysin were made. The most sensitive range for lysis of this clot was found to be between three and eight minutes. A lysis time of five minutes was arbitrarily chosen to represent 100 units of fibrinolysin. The human, dog and bovine enzyme dilution curves were oriented at five minutes, equaling 100 units, and found to coincide almost exactly (Figure 1). Each point in Figure 1 represents the average of at least three determinations. Comparison of the lysis time produced by an unknown solution with the figures in this reference curve allows translation of "times" to "units."

Assay of antifibrinolysin (antilysin): We defined 1 unit of antifibrinolysin as that amount which would completely inhibit the activity of 1 unit of fibrinolysin after one hour incubation at $29^{\circ} \mathrm{C}$. Routinely, $0.5 \mathrm{cc}$. of human Fraction III-3, containing approximately 200 units, was incubated for one hour at $29^{\circ} \mathrm{C}$. with (a) $0.5 \mathrm{cc}$. buffer and (b) $0.5 \mathrm{cc}$. serum or other antilysin, diluted so that the final lysis time would be 20 minutes or less. After incubation, the lysis time of each mixture was obtained and converted to fibrinolysin units by reference to the curve in Figure 1. Antifibrinolysin units per cc. were obtained by multiplying the unit difference by the serum dilution.

Preliminary tests had shown that the fibrinolysin-antifibrinolysin reaction required between 15 minutes and one hour for completion at $29^{\circ} \mathrm{C}$. Employing fibrinolysins of 160,180 , and 200 units and constant amounts of serum, the calculated serum antilysin titer was found to be independent of the initial lysin concentration. The determination of serum antilysin titer was also found to be independent of the concentration of serum added to the test system so long as the final lysis time was less than 20 minutes. Simultaneous multiple antilysin determinations on the same serum gave identical results. The mean serum antilysin titer for a group of 18 dogs was 2225

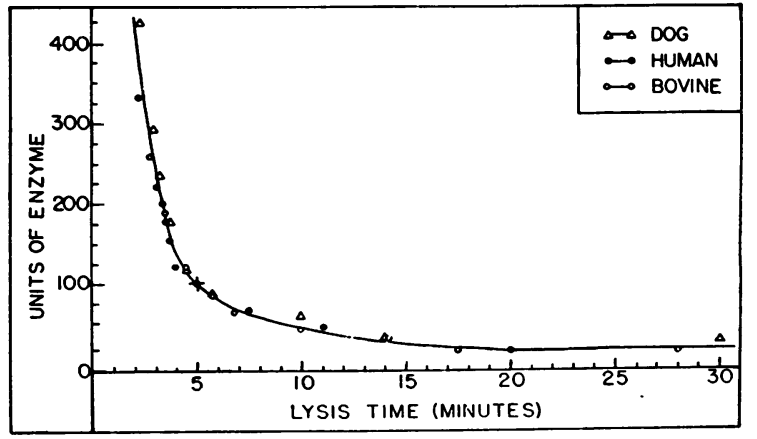

Fig. 1. Lysis Times of Standard Fibrin Clot in Relation to Varying Concentration of FibrinolySins: Human $(\bullet), \operatorname{Dog}(\triangle), \operatorname{Bovine}(O)$ 
units with a standard deviation ${ }^{4}= \pm 278$. Freezing and storage for periods up to one month at $-20^{\circ} \mathrm{C}$. apparently did not affect the antifibrinolysin titer of serum.

\section{RESULTS}

1. Species specificity of antilysin. Human, dog, and bovine lysin solutions of approximately equal strength (200 units) were prepared and antilysin titers of human, dog, and bovine serum run against each lysin. Pooled sera obtained from three to six donors were employed. The results, shown in Table I, are illustrative of four such experiments. No species specificity of one inhibitor for its homologous enzyme was demonstrated. The relative antilysin titers for the three species were approximately the same regardless of the lysin preparation used, although the absolute titers varied with the lysin. Bovine serum showed the largest antilysin content, human serum next and dog serum least. This order of antifibrinolysin titer is similar to that published by Guest and his associates (3).

TABLE I

Antifibrinolysin titers of human, dog, and bovine serum tested against human, dog, and bovine fibrinolysins

\begin{tabular}{l|c|c|c}
\hline \multirow{3}{*}{ Fibrinolysins } & \multicolumn{2}{|c}{ Antifibrinolysin titer-units/cc. } \\
\cline { 2 - 4 } & Human serum & Dog serum & Bovine serum \\
\hline Human & 2,200 & 2,000 & 6,750 \\
Dog & 8,000 & 6,250 & 27,000 \\
Bovine & 3,250 & 2,250 & 8,250 \\
\hline
\end{tabular}

2. Comparison of purified proteolytic enzyme inhibitors with serum antilysin. A constant amount of Human Fraction III-3 was treated with varying quantities of each of the inhibitory agents : SBI, NBI, Pan I, HS, and LA, and incorporated immediately into the standard clot. Approximately 60 antilysin units were initially present in $0.5 \mathrm{cc}$. of each of the inhibitors prepared in the following percentage concentrations: SBI, 0.0005 ; NBI, 0.01 ; Pan I, 0.1 ; LA, 1.0 ; and human serum in a five-fold dilution. Using these concentrations, the five inhibitors and buffer (control) were separately incubated at $29^{\circ} \mathrm{C}$. and at $37^{\circ} \mathrm{C}$. with equal amounts of Fraction III-3. Each mixture was sampled and tested for lysis time at the intervals

$$
{ }^{4} \mathrm{SD}=\sqrt{\frac{\Sigma d^{2}}{N-1}} .
$$

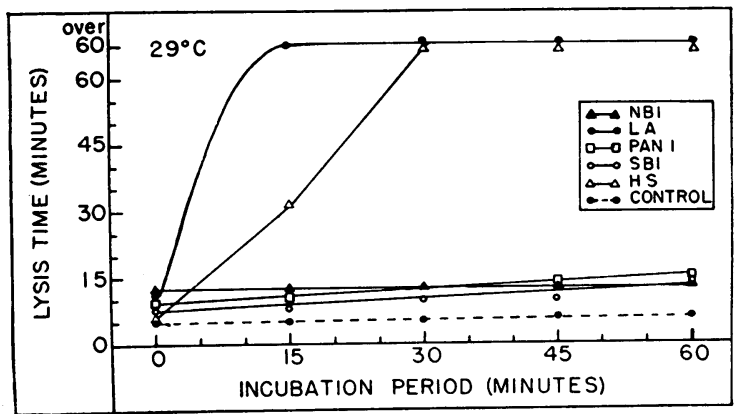

Fig. 2. Effects of Incubation, at $29^{\circ}$ C., of Various Inhibitors on Lysis Time Produced by a Standard FibRINOLYSIN

shown in Figures 2 and 3. Incubation at $29^{\circ} \mathrm{C}$ (Figure 2) resulted in marked increase in the inhibitory effects of the serum antilysins, HS and LA, while the effects of the purified preparations did not change significantly. Incubation at $37^{\circ} \mathrm{C}$. (Figure 3 ) caused rapid deterioration of the control lysin solution. SBI and NBI apparently partially prevented this deterioration.

3. Can the fibrinolysin-antifibrinolysin complex be separated into its component parts? We attempted to remove antilysin from a lysin-antilysin mixture by chloroform treatment. Mixtures $\mathrm{A}$, $\mathrm{B}$, and $\mathrm{C}$ (Table II) contained respectively: (A) $2.5 \mathrm{cc}$. of 0.6 per cent bovine fibrinolysin $+2.5 \mathrm{cc}$. buffer ; (B) 2.5 cc. of 0.6 per cent bovine fibrinolysin $+2.5 \mathrm{cc}$. of 0.2 per cent bovine antifibrinolysin; and (C) $2.5 \mathrm{cc}$. of 0.2 per cent bovine antifibrinolysin $+2.5 \mathrm{cc}$. buffer. Each mixture was allowed to incubate for one hour at $29^{\circ} \mathrm{C}$. and divided into two portions, one of which was shaken for two minutes with one-half volume of chloroform. Both portions

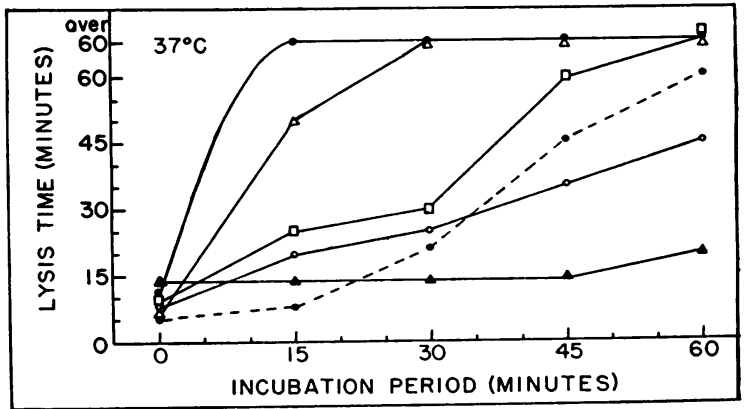

Fig. 3. EfFects of Incubation, at $37^{\circ} \mathrm{C}$., of Various Inhibitors on Lysis Time Produced by a Standard FibRINOLYSIN

Symbols as in Figure 2. 
TABLE II

Effects of chloroform treatment on the fibrinolysinantifibrinolysin complex (see text)

Mixture

A. Fibrinolysin buffer Untreated Lysis times

$4 \min$.

$48 \mathrm{hrs}$.

B. Fibrinolysin antifibrinolysin

C. Antifibrinolysin

buffer

5 hrs. 48 hrs.

of $\mathrm{A}$ and $\mathrm{B}$ were tested for lysis of the standard clot and both portions of $\mathrm{C}$ for antilysin titer. The chloroform treatment resulted in the rapid destruction of active lysin. In $\mathrm{A}$, this is shown by the great prolongation of lysis time from four minutes to 48 hours. In $\mathrm{B}$, if release of the fibrinolysin from the enzyme-inhibitor complex had occurred by destruction of antilysin, a shorter lysis time after chloroform treatment might be expected. The fact that considerable prolongation of the lysis time was observed showed that, as in A, the fibrinolysin was destroyed. In $\mathrm{C}$, the chloroform treatment resulted in about a 50 per cent reduction in antilysin titer.

4. Are the products of fibrinolysis inhibitory? The following experiments were set up to test this hypothesis.

Experiment 1. A strong Fraction III-3 solution was incorporated into the fibrin clot and, immediately after lysis was completed, $1.5 \mathrm{cc}$. of the lysed clot was again added to fresh fibrinogen and thrombin. As shown in Table III this procedure was repeated through six successive clots. In a control series, with the successive dilutions made at exactly the same time intervals, buffer was substituted for the fibrinogen until the last tube which was clotted and lysed as usual. The final lysis times, although not quite identical, were sufficiently close to suggest that no significant accumulation of inhibitory products had occurred during the re-

TABLE III

Effects of products of fibrinolysis on fibrinolysis

Time of addition
of sample
0
$1^{\prime} 25^{\prime \prime}$
$3^{\prime}$
$5^{\prime} 15^{\prime \prime}$
$8^{\prime}$
$11^{\prime} 35^{\prime \prime}$

$\begin{array}{cc}\text { Fibrinogen } & \text { Lysis time } \\ 1^{\prime} & \text { Control } \\ 1^{\prime} 20^{\prime \prime} & - \\ 2^{\prime} & - \\ 2^{\prime} 30^{\prime \prime} & - \\ 3^{\prime} 15^{\prime \prime} & - \\ 5^{\prime} 40^{\prime \prime} & -\end{array}$

TABLE IV

Effects of buffer, fibrinolysin-fibrinogen, and fibrinolysin-buffer mixtures, aged 24 hours at $37^{\circ} \mathrm{C}$., on the lysis time produced by a fresh fibrinolysin solution

\begin{tabular}{l|l|l|l}
\hline \multirow{2}{*}{ Aged mixture } & \multicolumn{3}{|c}{ Experiment } \\
\cline { 2 - 4 } & I & II & III \\
\hline Buffer & $3^{\prime} 30^{\prime \prime}$ & $4^{\prime}$ & $4^{\prime}$ \\
\hline Lysin + fibrinogen & $3^{\prime} 30^{\prime \prime}$ & $4^{\prime}$ & $4^{\prime}$ \\
\hline Lysin + buffer & $3^{\prime} 45^{\prime \prime}$ & $4^{\prime} 45^{\prime \prime}$ & $4^{\prime} 45^{\prime \prime}$ \\
\hline
\end{tabular}

peated lysis of fibrin. Repetition of this experiment provided similar results.

Experiment 2. In this experiment 5 cc. of 0.5 per cent Fraction III-3 and $5 \mathrm{cc}$. of 1 per cent bovine Fraction I (fibrinogen) were allowed 24 hours at $37^{\circ} \mathrm{C}$. for interaction before testing for development of inhibitory products. After aging of the fibrinolysin-fibrinogen mixture and controls consisting of fibrinolysin with buffer, and buffer alone, $1 \mathrm{cc}$. of each mixture was incubated with $0.5 \mathrm{cc}$. of a fresh Fraction III-3 solution for one hour at $29^{\circ} \mathrm{C}$. to allow full development of any antifibrinolytic effect. Three (I, II, III) such experiments were performed on different days. The results, presented in Table IV, showed that the aged fibrinolysin-fibrinogen mixture caused no prolongation of the lysis time of the fresh enzyme. The aged fibrinolysin-buffer mixture did cause some prolongation of the lysis time, which was consistent in the three experiments and perhaps significant. Preliminary tests on the aged mixtures showed that the fibrinolysin in each had almost completely deteriorated (lysis time over 48 hours) and, therefore, could not have played an additional role. No change in $\mathrm{pH}$ was observed in the aged mixtures.

\section{DISCUSSION}

Serum antifibrinolysins apparently show no species specificity for their homologous fibrinolysins. This and the fact that fibrinolysins, prepared from three sources: human, dog, and bovine serum, show similar activity curves when diluted (Figure 1) suggest that it is justifiable to use a single enzyme preparation for assay of antifibrinolysin in the various species. Our observations that bovine serum contains the greatest antifibrinolysin content, human serum next and dog serum least, 
confirms in a qualitative fashion the findings of Guest and his colleagues (3).

Purified trypsin inhibitors derived from soybean, navy bean, and pancreas exert their inhibitory action immediately and incubation with the enzyme does not increase this action. On the other hand, serum antifibrinolysins require high concentrations for immediate inhibitory action, but if low concentrations are allowed to incubate with fibrinolysin for at least 15 to 30 minutes at $29^{\circ} \mathrm{C}$., their inhibitory effects become marked. An interesting observation was noted when SBI and NBI were incubated with fibrinolysin at $37^{\circ} \mathrm{C}$. The fibrinolysin alone rapidly deteriorated, but in the presence of SBI and NBI this spontaneous deterioration was in part prevented, suggesting a "protecting influence" of the inhibitors.

In attempting to understand the nature of the fibrinolysin-antifibrinolysin reaction, we tried, by chloroform treatment, to remove antifibrinolysin after it had been allowed to react with fibrinolysin. Loomis' antifibrinolysin was employed in this experiment and was only about 50 per cent destroyed by chloroform treatment. This was not unexpected in view of the incomplete removal of antilysin from bovine serum by chloroform treatment (13). Furthermore, chloroform was found to destroy active lysin. This might be interpreted as additional evidence that serum itself contains profibrinolysin (prolysin) and not active lysin in combination with an inhibitor, as chloroform treatment of serum (notably dog) removes antilysin, but apparently does not destroy prolysin (13).

Two experiments were performed in an attempt to demonstrate antilytic effects of products of fibrinolysis. In the first experiment, a strong enzyme was allowed to lyse fibrin and the mixture of lysed fibrin and enzyme transferred repeatedly to fresh fibrin clots. The observed prolongation of lysis time could be almost completely accounted for by dilution and slight deterioration of the control enzyme. In the second experiment, fibrinoly$\sin$ and fibrinogen were allowed to react for 24 hours and then tested for inhibitory effects against a fresh enzyme solution. No inhibitory effects of this lysed fibrinogen could be detected.

\section{CONCLUSIONS}

1. Antifibrinolysins of human, dog and bovine origin did not show specificity for fibrinolysins prepared from sera of the same species.
2. Serum antifibrinolysins differed from purified trypsin inhibitors, derived from soybean, navy bean and pancreas, in their action on fibrinolysin. Serum inhibitors required a period of time for their maximal action, while purified inhibitors acted immediately and in very low concentrations.

3. Chloroform treatment destroyed active fibrinolysin as well as antifibrinolysin, and could not be used as a method of separation of the fibrinolysin-antifibrinolysin complex.

4. No evidence could be obtained to suggest that the products of fibrinolysis are inhibitory to fibrinolysin.

\section{BIBLIOGRAPHY}

1. Grob, D., The antiproteolytic activity of serum; nature and experimental variation of antiproteolytic activity of serum. J. Gen. Physiol., 1943, 26, 405.

2. Kaplan, M. H., Studies of streptococcal fibrinolysis. II. The inhibition of streptococcal fibrinolysis by antifibrinolysin and antiprotease. J. Clin. Invest., 1946, 25, 337.

3. Guest, M. M., Daly, B. M., Ware, A. G., and Seegers, W. H., A study of antifibrinolysin activity in the plasmas of various animal species. J. Clin. Invest., 1948, 27, 785.

4. Loomis, E. C., Ryder, A., and George, C., Jr., Fibrinolysin and antifibrinolysin: biochemical concentration of antifibrinolysin. Arch. Biochem., 1949, 20, 444.

5. Hedin, S. G., Über die Aufnahme von Trypsin durch verschiedene Substanzen. Ztschr. f. physiol. Chem., 1907, 50, 497.

6. Bayliss, W. M., The kinetics of tryptic action. Arch. biol. nauk., 1904, 11, Suppl., 261.

7. Northrop, J. H., Does kinetics of trypsin digestion depend on the formation of a compound between enzyme and substrate? J. Gen. Physiol., 1922, 4, 487.

8. Edsall, J. T., The plasma proteins and their fractionation, in: Advances in Protein Chemistry, Vol. 3 ; Anson, M. L., and Edsall, J. T., Editors. Academic Press Inc., New York, 1947, p. 383.

9. Loomis, E. C., George, C., Jr., and Ryder, A. Fibrinolysin; nomenclature, unit, assay, preparation and properties. Arch. Biochem., 1947, 12, 1.

10. Kunitz, M., Crystalline soybean trypsin inhibitor. J. Gen. Physiol., 1946, 29, 149.

11. Bowman, D. E., Fractions derived from soy beans and navy beans which retard tryptic digestion of casein. Proc. Soc. Exper. Biol. \& Med., 1944, 57, 139.

12. Guest, M. M., Ware, A. G., and Seegers, W. H., A quantitative study of antifibrinolysin in chick plasma: Increase in antifibrinolysin activity during pteroylglutamic acid deficiency. Am. J. Physiol., 1947, 150, 661.

13. Lewis, J. H., and Ferguson, J. H., To be published. 